\title{
The profile of acute glomerulonephritis among Indonesian children
}

\author{
Husein Albar, Syarifuddin Rauf
}

\begin{abstract}
Background Acute glomerulonephritis (AGN) is a form of glomerulonephritis characterized by sudden and explosive onset of glomerular injury symptom. It usually occurs after recent infection by group A beta-hemolytic streptococcus. AGN among Indonesian children seems to be less frequently reported than that among other countries.

Objective To determine the current profile of AGN among Indonesian children hospitalized in eleven teaching centers.

Methods This was a descriptive, cross-sectional study, based on a review of the standard medical records of 509 children with AGN hospitalized in 11 teaching centers in Indonesia over a five-year period (1997-2002). Data extracted from the medical records consisted of history of illness, clinical and laboratory findings, and chest X-rays.

Results Age of the patients at the onset of AGN ranged from 2.5 to 15 years, with peak age of 8.5 years. The majority (76.4\%) was above 6 years old with male predominance (58.3\%). About $68.9 \%$ and $82 \%$ of the patients came from low socioeconomic and low educational status families. Antecedent upper respiratory infections were observed in $45.8 \%$ cases and pyoderma in $31.6 \%$. The disease seemed to be more commonly elicited by streptococcal infection than by other infections, as proved by an elevated anti-streptolisin $\mathrm{O}$ (ASO) titer (66.6\%) and decreased $\mathrm{C}_{3}$ concentrations $(60.4 \%)$. The frequent clinical features included periorbital edema $(76.3 \%)$, hypertension (61.8\%), and gross hematuria (53.6\%). The most prevalent laboratory findings were microhematuria $(99.3 \%)$, proteinuria $(98.5 \%)$, raised erythrocyte sedimentation rate $(85.3 \%)$. The initial chest X-rays showed pleural effusion (81.6\%) and cardiomegaly $(80.2 \%)$, whereas echocardiogram documented pericardial effusion $(81.6 \%)$. Acute pulmonary edema (11.5\%), hypertensive encephalopathy $(9.2 \%)$, and acute renal failure $(10.5 \%)$ were frequent complications noted in our study.

Conclusion Despite no adequate data on throat or skin cultures, AGN among Indonesian children seems mostly to be poststreptococcal AGN as proved by the elevated ASO titer and decrease in serum $\mathrm{C}_{3}$ concentration [Pediatr Indones 2005;45:264-269].
\end{abstract}

Keywords: acute glomerulonephritis, poststreptococcal glomerulonephritis, Indonesian children
1

cute glomerulonephritis (AGN) is a form of glomerulonephritis characterized by a sudden and often explosive onset of symptoms of glomerular injury, including hematuria, hypertension, edema, and varying degrees of renal insufficiency. ${ }^{1}$ It usually occurs after a recent infection by group A beta-hemolytic streptococcus, and therefore known as post-strepococcal acute glomerulonephritis (PSAGN). ${ }^{2}$ Nevertheless, the disease has been reported following other bacterial, viral, parasitic, rickettsial, and fungal infections, ${ }^{3}$ and known as non-poststreptococcal AGN (NPSAGN). AGN among Indonesian children seems to be less frequently reported than that among other countries. Therefore the Nephrology Working Group (NWG) of the Indonesian Society of Pediatricians coordinated a multi-center study in 11 teaching centers to determine the current profile of AGN among Indonesian children. The study was further conducted by the NWG of the Indonesian Society of Pediatricians, South Sulawesi branch-Hasanuddin University teaching center.

The objective of this study was to determine the current profile of AGN among Indonesian children hospitalized in eleven teaching centers.

From the Department of Child Health, Medical School, Hasanuddin University, Makassar, Indonesia.

Reprint requests to: Husein Albar, MD, Department of Child Health, Medical School, Hasanuddin University, Wahidin Sudirohusodo Hospital, Jl. Perintis Kemerdekaan, Km 11, Tamanlarea, Makassar, Indonesia. Tel./ Fax. 62-411-590738. 


\section{Methods}

This was a descriptive, cross-sectional study, based on a review of the standard medical records of all children hospitalized in eleven teaching centers with a diagnosis of AGN between January 1997 and January 2002. All children with AGN hospitalized at the centers over the five-year period were included in the study. Prior approval was obtained from the Ethical Committee of Wahidin Sudirohusodo Hospital, Makassar. The contributors of the data were the NWG of the Indonesian Society of Pediatricians in 11 teaching centers including Andalas University (Unand), Padang; Sriwijaya University (Unsri), Palembang; University of Sumatera Utara (USU), Medan; University of Indonesia (UI), Jakarta; Diponegoro University (Undip), Semarang; Gajah Mada University (UGM), Yogyakarta; Padjadjaran University (Unpad), Bandung; Airlangga University (Unair), Surabaya; Udayana University (Udayana), Bali; Hasanuddin University (Unhas), Makassar, and Sam Ratulangi University (Unsrat), Manado.

Data from the standard medical records of all patients, including of history of illness, clinical and laboratory findings, and chest X-rays were obtained. Echocardiography was performed on admission and after resolution of the clinical manifestations, by the Hasanuddin University teaching center to investigate the cause of cardiomegaly documented on the chest films. The diagnosis of PSAGN was established based on the following clinical and laboratory criteria: edema, hypertension, gross hematuria, and/or microhematuria with or without red blood cell casts in the urinary sediment, recent history of group A beta-hemolytic streptococcal infection demonstrated by an elevated antistreptolysin $\mathrm{O}(\mathrm{ASO})$ titer, and low serum $\mathrm{C}_{3}$ concentration. ${ }^{1,2,4,5}$ Patients who did not fulfill the above mentioned criteria were diagnosed as having NPSAGN. Hypertension was defined as systolic and/or diastolic blood pressure values exceeding the $95^{\text {th }}$ percentile for age and sex. ${ }^{6}$ Microhematuria was considered present if the red blood cell count was greater than 5 cells/high power field in centrifugated urine shown by light microscopy. Missing data was defined as no data documented in the standard medical records. Patients with complete standard medical records were further reviewed in this study.

\section{Results}

The number of subjects enrolled in this study was 509, consisting of $58.3 \%$ boys and $41.7 \%$ girls, with boy to girl ratio of 1.4:1. Age at the onset of AGN ranged from 2.5 to 15 years, with the peak age of 8.5 years. The majority was above 6 years at onset of AGN (76.4\%) (Table 1). About $68.9 \%$ of the patients came from low socioeconomic status families and $82 \%$ from low educational status families (Table 3 ).

According to the history of illness, we found that AGN was more frequently preceded by an upper respiratory tract infection (URTI) $(45.8 \%)$ than

Table 1. Clinical characteristics of patients With acute glomerulonephritis

\begin{tabular}{lcccccccc}
\hline $\begin{array}{l}\text { Teaching } \\
\text { centers }\end{array}$ & $\begin{array}{c}\text { Age }>\text { 6 years } \\
(\%)\end{array}$ & $\begin{array}{c}\text { Male } \\
\text { gender } \\
(\%)\end{array}$ & $\begin{array}{c}\text { Upper } \\
\text { respiratory } \\
\text { tract infection } \\
(\%)\end{array}$ & $\begin{array}{c}\text { Pyoderma } \\
(\%)\end{array}$ & $\begin{array}{c}\text { Edema } \\
(\%)\end{array}$ & $\begin{array}{c}\text { Gross } \\
\text { hematuria } \\
(\%)\end{array}$ & $\begin{array}{c}\text { Hypertension (\%)/ } \\
\text { Hypertensive } \\
\text { encephalopathy } \\
(\%)\end{array}$ & $\begin{array}{c}\text { Oliguria } \\
(\%)\end{array}$ \\
\hline Unand & 75.0 & 50.0 & 50.0 & 25.0 & 100.0 & 100.0 & $75.0 / 50.0$ & 25.0 \\
USU & 79.7 & 55.0 & 55.9 & 33.3 & 74.1 & 64.4 & $32.1 / 5.4$ & 20.8 \\
Unsri & 78.7 & 70.2 & 67.2 & 27.1 & 81.1 & 58.7 & $42.6 / 4.3$ & 17.0 \\
Ul & 74.7 & 53.5 & 43.7 & 14.1 & 79.7 & 47.9 & $57.1 / 6.4$ & 19.7 \\
Unpad & 83.3 & 69.9 & 50.1 & 25.0 & 84.4 & 25.0 & $94.4 / 12.0$ & 12.2 \\
Undip & 84.8 & 54.5 & 30.3 & 40.6 & 75.8 & 30.3 & $72.7 / 00.0$ & 15.2 \\
UGM & 83.3 & 75.0 & 43.5 & 33.3 & 74.5 & 52.1 & $79.2 / 12.7$ & 14.8 \\
Unair & 81.4 & 62.3 & 21.4 & 48.3 & 81.1 & 68.6 & $74.6 / 12.4$ & 11.8 \\
Udayana & 51.7 & 55.2 & 69.7 & 14.2 & 76.9 & 42.0 & $63.0 / 11.1$ & 24.8 \\
Unhas & 79.6 & 51.1 & 32.7 & 34.9 & 84.9 & 56.8 & $71.4 / 8.2$ & 14.6 \\
Unsrat & 65.1 & 52.4 & 60.1 & 30.0 & 70.0 & 46.0 & $63.9 / 8.2$ & 26.7 \\
\hline Total & 76.4 & 58.2 & 45.8 & 31.6 & 76.3 & 53.6 & $61.8 / 9.2$ & 23.9 \\
\hline
\end{tabular}


Paediatrica Indonesiana

Table 2. Laboratory features of Patients With acute glomerulonephritis

\begin{tabular}{lccccccccc}
\hline $\begin{array}{l}\text { Teaching } \\
\text { centers }\end{array}$ & $\begin{array}{c}\text { MH } \\
(\%)\end{array}$ & $\begin{array}{c}\text { PTR } \\
(\%)\end{array}$ & $\begin{array}{c}\text { NRP } \\
(\%)\end{array}$ & $\begin{array}{c}\text { RBCc } \\
(\%)\end{array}$ & $\begin{array}{c}\text { RESR } \\
(\%)\end{array}$ & $\begin{array}{c}\text { LHB } \\
(\%)\end{array}$ & $\begin{array}{c}\text { AZA } \\
(\%)\end{array}$ & HASO & LSC $_{3}$ \\
\hline Unand & 100.0 & 100.0 & 25 & 25.0 & 100.0 & 25.0 & 50.0 & 100.0 & 100.0 \\
USU & 84.0 & 69.6 & 6.5 & 45.0 & 68.3 & 70.4 & 20.4 & 54.1 & 57.7 \\
Unsri & 87.0 & 99.7 & 2.3 & 16.7 & 71.1 & 59.6 & 10.6 & 93.6 & 51.1 \\
Ul & 90.8 & 89.7 & 4.3 & 16.9 & 96.0 & 77.9 & 09.1 & 42.3 & 52.1 \\
Unpad & 94.4 & 84.7 & 4.3 & 2.9 & 66.7 & 82.4 & 06.7 & 63.9 & 30.6 \\
Undip & 100.0 & 84.8 & 4.3 & 40.8 & 66.9 & 41.7 & 21.2 & 57.6 & 48.5 \\
UGM & 96.0 & 84.9 & 4.5 & 42.3 & 96.0 & 41.7 & 09.1 & 76.3 & 90.6 \\
Unair & 100.0 & 100.0 & 4.3 & 40.8 & 80.0 & 54.0 & 16.1 & 79.2 & 80.6 \\
Udayana & 100.0 & 79.3 & 0.0 & 16.8 & 50.0 & 69.2 & 23.8 & 58.6 & 58.6 \\
Unhas & 95.7 & 87.8 & 6.0 & 60.9 & 68.0 & 51.0 & 14.8 & 98.0 & 91.8 \\
Unsrat & 96.5 & 99.7 & 2.2 & 42.7 & 78.6 & 52.4 & 18.2 & 50.9 & 50.9 \\
\hline Total & 99.3 & 98.5 & 6.0 & 44.3 & 85.3 & 61.0 & 19.1 & 66.6 & 60.4 \\
\hline
\end{tabular}

TC: teaching centers, MH: microhematuria, PTR: proteinuria, NRP: nephrotic range proteinuria, AZA: azotemia, RBCc: red blood cells casts, RESR: raised erythrocyte sedimentation rate, LHB: low hemoglobin level, HASO: high anti-streptolysin $\mathrm{O}$ titer, $\mathrm{LSC}_{3}$ : low serum $\mathrm{C}_{3}$ level

by pyoderma (32.6\%) (Table 1$)$. The disease seemed to be more commonly elicited by streptococcal infection (PSAGN) than by other infections (NPSAGN), as proved by an elevated ASO titer (66.6\%) and decreased $\mathrm{C}_{3}$ concentrations (60.4\%) (Table 2). The frequently observed clinical presentations were periorbital edema $(76.3 \%)$, hypertension $(61.8 \%)$, gross hematuria $(53.6 \%)$, and oliguria (23.9\%) (Table 2).

Table 2 shows the abnormalities of laboratory findings in our cases. The majority of patients had proteinuria $(98.5 \%)$, and microhematuria $(99.3 \%)$ while the remaining of the patients had elevated erytrhrocyte sedimentation rate (ESR) (85.3\%), anemia $(61.0 \%)$ as shown by hemoglobin levels $\leq 10 \mathrm{~g} /$ $\mathrm{dl}$, red blood cell (RBC) casts on urinary sediments (44.3\%), azotemia (10.5\%) consisting of elevated serum ureum and creatinine, mild hypercholesterolemia $(5.7 \%)$, and mild hypoproteinemia (4.7\%), respectively.

Chest X-ray examinations revealed the presence of cardiomegaly and pleural effusion in $80.2 \%$ and $81.6 \%$ of cases, respectively, and echocardiography demonstrated pericardial effusion in $81.6 \%$. Acute pulmonary edema $(11.5 \%)$ was the most common complication observed besides hypertensive encephalopathy $(9.2 \%)$ and acute renal failure (10.5\%) (Table $3)$. As shown in Table 3, all patients recovered within $7-14$ days with the majority of patients $(73.5 \%)$ recovered within 12 days.

\section{Discussion}

This study seems to be one of the large published series of AGN cases to date. Several studies indicated that AGN was more commonly encountered in children older than 6 years. More boys than girls were affected; other studies have reported a ratio of $2: 1,4,7-10$ and 3:2.5 A study in Benin city noted the peak incidence at 3 years for both sexes, with female predominance. ${ }^{11}$ Meanwhile, a report from Armenia showed that the majority of patients was boys in the age group 4-9 years. ${ }^{12}$ Our study showed that most patients with AGN were older than 6 years with a boy to girl ratio of 1.4:1. Our subjects were of lower socioeconomic status than those in the study in Benin city.

In the present study antecedent URTI was observed in $45.8 \%$ of cases and pyoderma in $32.6 \%$ of cases. The disease seems to be more commonly caused by streptococcal infections (PSAGN) than by other agents (PSAGN). Elevated ASO titer (66.6\%) and decreased $\mathrm{C}_{3}$ concentrations $(60.4 \%)$ were objective evidence of recent streptococcal infection prior to AGN in our cases. Puri et $a^{15}$ and Manhas et all ${ }^{13}$ reported pyoderma as the most common antecedent infection $(67.5 \%$ and $60 \%)$. Others reported a significant rise in ASO titer (70-80\%) following pharyngitis-related $\mathrm{AGN}^{1,15,16}$ and a decreased serum $\mathrm{C}_{3}$ concentration (80-96\%). ${ }^{1,7,8}$ In the cases we reviewed, measurement of ASO titers and $\mathrm{C}_{3}$ consentrations were done only on admission and were not repeated 
during hospitalization, resulting in figures different from those in other studies. The frequently observed clinical presentations in our patients included periorbital edema (76.3\%), hypertension $(61.8 \%)$, gross hematuria (53.6\%), and oliguria (23.9\%). These data relatively agreed with those from previous reports. Ibadin and Abiodun ${ }^{11}$ reported edema in $93.7 \%$ of their patients, Manhas et al ${ }^{13}$ in 83,4\%, and Lewy in $66.7 \%$. Gross hematuria occurred in $30-70 \%$ of children with AGN and microhematuria was present in almost all children with AGN. 1,4,7,8,16,17 Hematuria and proteinuria of varying degrees occurred in all children with AGN in Ibadin and Abioudin's study, ${ }^{11}$ but hypertension and oligouria were observed only in $82.5 \%$ and $47.6 \%$ of children, respectively, which is higher than the figures in our study. Hypertension reported by Rubin ${ }^{16}$ (60-70\%) was similar to the present study and oliguria ${ }^{1,16}$ was much lower (5-
$10 \%)$ than that observed in our patients. The incidence of hypertensive encephalopathy observed in our study (6\%) is similar to previous study $(5-10 \%)$.

Lewy ${ }^{7}$ observed azotemia in a higher proportion of subjects than we did. RBC casts were found in a much lower proportion of our patients $(44.3 \%)$ than that observed by Travis and Kalian ${ }^{1}$ (60-85\%). The proportion of elevated ESR in our cases was higher than that reported by Manhas et al ${ }^{13}$ (19.8\%), but slightly lower than Puri et al ${ }^{15}$ (95\%). Anemia as indicated by hemoglobin levels $\leq 10 \mathrm{~g} / \mathrm{dl}$ was reported by Puri et all (44\%) and Manhas et all ${ }^{13}$ (27.1\%) in lower proportions of patients than in the present observations (61\%). Reduction in $\mathrm{Hb}$ and hematocrit is believed to be due to hemodilution as well as hematuria. Hypoproteinemia is also in part due to the dilutional effect of intravascular volume expansion. ${ }^{1,17}$

Table 3. Published studies of acute glomerulonephritis in Children

\begin{tabular}{|c|c|c|c|c|c|c|}
\hline $\begin{array}{l}\text { Clinical, laboratory, } \\
\text { and x-ray findings }\end{array}$ & $\begin{array}{l}\text { The present } \\
\text { study } \\
1997-2002 \\
\text { (509 patients) }\end{array}$ & $\begin{array}{l}\text { Srinagar } \\
\text { Kashmir }^{13} \\
\text { 1976-1978 } \\
\text { (350 patients) }\end{array}$ & $\begin{array}{l}\text { Pondychery } \\
\text { India }^{15} \\
1966-1973 \\
\text { (350 patients) }\end{array}$ & $\begin{array}{l}\text { Iraq } \\
1993-1997^{21} \\
\text { (47 patients) }\end{array}$ & $\begin{array}{l}\text { Memphis } \\
\text { USA }^{19} \\
\text { 1979-1988 } \\
\text { (95 patients) }\end{array}$ & $\begin{array}{l}\text { Armenia }^{12} \\
\text { 1992-1996 } \\
\text { (474 patients) }\end{array}$ \\
\hline Age range/years & $2.5-15$ & $2-14$ & & $3-14$ & $2-15$ & $1-16$ \\
\hline The majority of age (years) & $>6(76.4 \%)$ & $>5-12(98.3 \%)$ & $3-8(63 \%)$ & $5-10(70.2 \%)$ & & $>4-9(62 \%)$ \\
\hline The peak age (years) & 8.46 & $5-8$ & $>8(28 \%)$ & 8.2 & $8.2 \pm 3.6$ & 7.5 \\
\hline Boy:girl ratio & $1.39: 1$ & $1.94: 1$ & $1.44: 1$ & $2.35: 1$ & $2.27: 1$ & $1.88: 1$ \\
\hline Low socioeconomic status & $68.9 \%$ & $66.9 \%$ & & & & \\
\hline Low educational status & $82 \%$ & & & & & \\
\hline Edema & $76.3 \%$ & $83.4 \%$ & $100 \%$ & $87 \%$ & $82.10 \%$ & $84 \%$ \\
\hline Gross hematuria & $53.6 \%$ & $31.4 \%$ & $55.6 \%$ & & $54.7 \%$ & $93 \%$ \\
\hline Hypertension & $61.8 \%$ & $69.1 \%$ & $74.6 \%$ & $87 \%$ & $73.7 \%$ & $72 \%$ \\
\hline Oliguria & $23.9 \%$ & $90 \%$ & $85.7 \%$ & $100 \%$ & & \\
\hline $\begin{array}{l}\text { Hypertensive } \\
\text { encephalopathy }\end{array}$ & $9.2 \%$ & $3.4 \%$ & & & & \\
\hline Acute pulmonary edema & $11.5 \%$ & & & & & \\
\hline $\begin{array}{l}\text { Upper respiratory tract } \\
\text { infection }\end{array}$ & $45.8 \%$ & $20 \%$ & $31 \%$ & & $62.1 \%$ & $51 \%$ \\
\hline Pyoderma & $31.6 \%$ & $60 \%$ & $67.5 \%$ & & $37.9 \%$ & $13 \%$ \\
\hline Microhematuria & $99.3 \%$ & $98.5 \%$ & $100 \%$ & $100 \%$ & & $100 \%$ \\
\hline Red blood cell casts & $44.3 \%$ & $37.1 \%$ & $89.6 \%$ & & $80 \%$ & \\
\hline Proteinuria & $98.5 \%$ & $99.4 \%$ & $100 \%$ & & & \\
\hline Nephrotic range proteinuria & $6 \%$ & $8.6 \%$ & $9.9 \%$ & & $27.3 \%$ & \\
\hline Elevated anti-streptolisin O & $66.6 \%$ & & $75 \%$ & $33.3 \%$ & $78.9 \%$ & \\
\hline Low complement $\mathrm{C}_{3}$ & $60.4 \%$ & & & & $81.1 \%$ & $95 \%$ \\
\hline Hemoglobin $<10 \mathrm{~g} / \mathrm{dL}$ & $61.0 \%$ & $27.1 \%$ & $100 \%$ & & & \\
\hline Elevated ESR & $85.3 \%$ & $19.8 \%$ & $95 \%$ & & & \\
\hline Azotemia & $10.5 \%$ & $42.6 \%$ & $65.1 \%$ & $50 \%$ & & $29 \%$ \\
\hline Hypoproteinemia & $4.7 \%$ & & & & & \\
\hline Hypercholesterolemia & $5.7 \%$ & & & & & \\
\hline Pleural effusion & $81.6 \%$ & $0.3 \%$ & $52 \%$ & & & \\
\hline Cardiomegaly & $80.2 \%$ & $19.4 \%$ & $72 \%$ & & & \\
\hline Pericardial effusion & $81.6 \%$ & & & & & \\
\hline Average hospital stay (days) & 12 & 7 & & 7.9 & & \\
\hline
\end{tabular}


The frequent complications of $\mathrm{AGN}$ in the present study including acute pulmonary edema (11.5\%), hypertensive encephalopathy $(9.2 \%)$, and acute renal failure $(10.5 \%)$ were relatively consistent in proportion with observations by Ibadin and Abiodun $^{11}$ (39.7\%, 4.8\% and $\left.12.7 \%\right)$. Radiological abnormalities in our study (81.6\%) seems to be consistent with that observed by Kirckpatrick et al ${ }^{20}$ (85.5\%) and Puri et al ${ }^{15}$ (72\%) but higher than by Manhas et al ${ }^{13}$ (19.4\%). To investigate the cause of cardiomegaly, Unhas teaching center performed echocardiography. The initial chest films and echocardiograms (81.6\%) demonstrated cardiomegaly and pericardial effusion, but after recovery the follow-up examinations showed that both had disappeared simultaneously. It means that cardiomegaly in our patients with AGN mainly resulted from pericardial effusion.

Table 3 shows the similarities and differences of observations between our study and other investigators. ${ }^{12,13,15,19,21}$

Patients with AGN have an expanded extracellular fluid volume secondary due to sodium and water retention leading to clinical manifestations of AGN and generalized circulatory congestion. Although circulatory congestion is similar to primary fluid overload, there is no evidence of abnormality in the heart

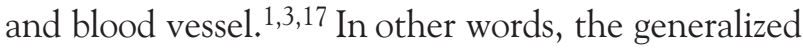
circulatory congestion is merely of renal origin. Complete recovery observed in our study ranged from 7 to 14 days with the majority of patients in 12 days; Iraqi patients mostly recovered within 2 weeks with average time of recovery 7.9 days ${ }^{21}$ while Kashmiri children 7 days. ${ }^{13}$ The different results observed in our study might be caused by the limitations of the study; we did not perform repeated examinations during hospitalization beside the difference in methodology, geography, and period of the study.

In conclusion, despite no adequate data on throat or skin cultures, AGN among Indonesian children seems mostly to be PSAGN as proved by the elevated $\mathrm{ASO}$ titer and decrease in $\mathrm{C}_{3}$ concentration.

\section{References}

1. Travis LB, Kalian. Acute nephritic syndrome. In: Postlethwaite, editor. Clinical paediatric nephrology. 2nd ed. ButterWorth-Heinamann Ltd. Linacre House: Jordan Hill; 1994. p. 201-9.

2. Behrman RE, Kliegman R. Acute poststreptococcal glomerulonephritis. In: Nelson's essentials of pediatrics. Philadelphia: WB Saunders and company; 1990. p. 566-7.

3. Fleisher DS, Voci G, Garfunkel J, Purungganan $\mathrm{H}$, Kirkpatrick JJ, Wells R, et al. Hemodynamic findings in acute glomerulonephritis. J Pediatr 1966;69:1054-62.

4. Jordan SC, Lemire JM. Acute glomerulonephritis. Pediatr Clin North Am 1982;29:857-73.

5. Kobrin S, Madaio MP. Postinfectious glomerulonephritis. In: Schier RW, Gottschalk CW, editors. Diseases of the kidney. Boston: Little Brown and company; 1997. p. 1579-94.

6. Report of the 2nd task force on blood pressure control in children. Pediatrics 1987;79:1.

7. Lewy JE. Acute poststreptococcal glomerulonephritis. Pediatr Clin North Am 1976;23:751-8.

8. Barrat TM. Glomerular disease and hematuria. In: William DI, Johnson JH, editors. Pediatric urology. 2nd ed. London: Butterworth company; 1982. p. 87.

9. Vogt A. Postinfectious and autoimmune glomerulonephritis: Are cationic antigens involved? Act med Bio 1991;39:17-29.

10. Schwartz WB, Kassrer JP. Clinical aspects of acute poststreptococcal glomerulonephritis. In: Strauss MB, Wel LG, editors. Disease of the kidney. 2nd ed. Boston: Little Brown and company; 1971. p. 419-52.

11. Ibadin OM, Abiodun O. Childhood acute glomerulonephritis in Benin City. Nigerian Journal of Pediatrics 2003;30:45-9.

12. Sarkissian A, Papazian M, Azatian G, Arikiants N, Babloyan A, Leumann E. An epidemic of acute postinfectious glomerulonephritis in Armenia. Arch Dis Child 1997;77:342-4.

13. Manhas RS, Patwari A, Raina C, Singh A. Acute nephritis in Kashmiri children-a clinical and epidemiological profile. Indian Pediatr 1979;16:1015-21.

14. Dodge WF, Spargo BH, Travis LB, Srivastava RN, Caryajal HF, DeBeukelaer MM, et al. Poststreptococcal glomerulonephritis. A prospective study in children. N Engl J Med 1972;286:273-8.

15. Puri RK, Khanna KK, Raghu MB. Acute glomerulonephritis in children. Indian Pediatr 1976;3:707-10.

16. Rubin MI. Glomerulonephritis. In: Rubin MI, Barret TM, editors. Pediatric nephrology. Baltimore: Williams and Wilkins company; 1975. p. 530-45. 
17. Brouhard BH, Travis LB. Acute postinfectious glomerulonephritis. In: Edelmann CM, editor. Pediatric kidney disease. 2nd ed. Boston: Little Brown and company; 1992. p. 1199-215.

18. James AJ. Renal disease in childhood. 2nd ed. St Louis: Mosby company; 1972. p. 175-85.

19. Roy S, Stapleton FB. Changing perspective in children hospitalized with poststreptococcal acute glomerulonephritis. Pediatr Nephrol 1990;4:585-8.

20. Kirkpatrick JA, Fleischer DS. The roentgen appearance of the chest in acute glomerulonephritis in children. J Pediatr 1964;64:492-8.

21. Al-Mosawi AJ. The pattern of acute glomerulonephritis in 47 Iraqi children. Pediatr Nephrol 2002;17:74-5. 